\title{
ARTYKUŁY
}

\author{
Agnieszka Helman-Ważny \\ Katedra Książki i Historii Mediów \\ Wydział Dziennikarstwa, Informacji i Bibliologii \\ Uniwersytet Warszawski, Warszawa, Polska \\ a.helman-wazny@uw.edu.pl \\ ORCID 0000-0003-1525-767X \\ http://doi.org/10.33077/zbkh.2018.12.helman
}

\section{Tybetańskie manuskrypty tradycji bön w Nepalu na przykładzie kolekcji z jaskiń Mardzong w Górnym Mustangu ${ }^{1}$}

\section{Abstract \\ Tibetan manuscripts of Bön tradition in Nepal: A case of the collection of manuscripts from the Mardzong caves in Upper Mustang}

Bön religious manuscripts were not traditionally seen as artefacts characterized by a distinguished form and technology. As a result, the numerous manuscripts of the Bön religion have not been clearly identified as a separate corpus so far, they have not been subjected to codicological and material research, despite their importance for the study of history and religions of Central Asia. Considering these perspectives, this article presents the current state of knowledge and the results of preliminary research on Bön manuscripts in Nepal. The main focus of this research is the collection of Mardzong manuscripts preserved in the Chöde Monastery in Lo Monthang in Mustang (Nepal).

Key words: Bön religion - Tibetan manuscripts - history - codicological study - manuscript dating. Słowa kluczowe: religia bön - tybetańskie manuskrypty - historia - badania kodykologiczne datowanie manuskryptów.

1 Badania naukowe finansowane przez Narodowe Centrum Nauki, grant 2014/14/E/HS3/00770. 


\section{Religia bön i jej tradycja piśmiennicza}

Bön, uważana przez Tybetańczyków za rdzenną religię ich kraju, jest połączeniem kilku autochtonicznych tradycji światopoglądowych, w tym buddyzmu indyjskiego, i szeregu endemicznych wierzeń. Znany obecnie korpus literatury bön składa się z kilku tysięcy tomów o szerokim zakresie tematów, często prezentujących sprzeczne poglądy na wszechświat. Dla zwolenników Jungdrung bön (tyb. g.yung drung bon) spójność tych odmiennych doktryn wywodzi się z przekonania, że wszystkie są naukami mitycznego założyciela religii Tönpy Szenraba (tyb. ston pa gshen rab) nazywanego również Szenrab Miwo (tyb. gshen rab mi bo).

W kontekście kulturowym manuskrypty tej tradycji, podobnie jak książki powstające na obszarze Tybetu, funkcjonowały głównie jako nośnik nauk religijnych. Zawierały teksty filozoficzne, religijne, medyczne, historyczne, astronomiczne lub rytualne. Do najstarszych i najbardziej typowych dla tej religii tekstów należą opowieści narracyjne zwane rabs lub smrang. Cathy Cantwell i Rob Mayer, zainspirowani wynikami badań Samtena Karmaya, tłumaczą ich pochodzenie i charakter w artykule opublikowanym w „Revue d'Etudes Tibétaines" z 2008 r. ${ }^{2}$ Jednym z ważnych odkryć S. Karmaya jest fakt, że we wczesnych formach ceremoniału bön każdemu rytuałowi towarzyszył archetypiczny mit, będący jednocześnie integralną częścią tego rytuału. W takim rozumieniu rytuał nie mógł funkcjonować bez odnoszącego się do niego mitu i także nie mógł być bez niego właściwie zrozumiany ${ }^{3}$. Tym bardziej, że tego typu teksty rytualne zawierają wiele archaicznych sformułowań i w przeciwieństwie do pism buddyzmu tybetańskiego nie nawiązują do indyjskich wzorów, które pozwalałyby na dodatkową interpretację.

Rękopisy zawierające takie teksty znaleziono w Dunhuangu (Grota nr 17, Mogao $)^{4}$ oraz w tybetańskim forcie Miran ${ }^{5}$. Niektóre z nich znane są od jakiegoś czasu, dzięki pracy takich uczonych jak Ariane Macdonald, Rolf Stein, Marcelle Lalou i S. Karmay ${ }^{6}$. Inne zostały odkryte dopiero niedawno. Teksty

2 C. Cantwell, R. Mayer, Enduring myths: «smrang», «rabs» and ritual in the Dunhuang texts on Padmasambhava, ,Revue d'Etudes Tibétaines” 2008, t. 15, s. 292.

3 S.G. Karmay, The Arrow and the Spindle. Studies in History, Myths, Rituals and Beliefs in Tibet. Vol. 1-3, Kathmandu 1998-2014, s. 245, 288.

4 W kompleksie buddyjskich jaskiń Mogao w okolic miasta Dunhuang położonego na dawnym Jedwabnym Szlaku w północno-zachodnich Chinach. W grocie nr 17 tegoż kompleksu jaskiń odkryto na początku XX w. zbiory starożytnych manuskryptów z różnych okresów historii buddyzmu datowane na pierwsze tysiąclecie do początku XI w.

5 Miran to starożytna oaza położona na Jedwabnym Szlaku we wschodniej części basenu Tarymu, na zachód od jeziora Lobnor (obecnie region autonomiczny Xinjiang w Chinach).

6 M. Lalou, Fiefs, poisons et guerisseurs, „Journal Asiatique” 1958, t. 246, s. 157-201; R.A. Stein, Du récit au rituel dans les manuscrits tibétains de Touen-Houang, [in:] Études tibétaines dédiées à la mémoire de Marcelle Lalou, ed. A. Spanien, Paris 1971, s. 479-547; A. Macdonald, 
te są zapisem faktycznych rytuałów odprawianych pod koniec tybetańskiego okresu imperialnego. Tak więc najprawdopodobniej niektóre rękopisy z Dunhuangu pochodzą z IX i X w. Dokumenty z fortecy Miran nie są starsze niż połowa IX w., kiedy to wojska tybetańskie straciły kontrolę nad regionem i fort został porzucony ${ }^{7}$. Obecnie manuskrypty te znajdują się głównie w zbiorach Biblioteki Brytyjskiej (British Library) i Biblioteki Narodowej Francji (Bibliothèque nationale de France). Kolejna kolekcja z tego samego okresu została niedawno odkryta w południowym Tybecie ${ }^{8}$.

Podobnie jak tybetańscy buddyści, wyznawcy bön mają zbiór tekstów kanonicznych, który tak jak w przypadku kanonu buddyjskiego jest podzielony na dwie główne części. Tak więc kanon bön składa się z Kandżuru (tyb. bka' 'gyur, ok. 170 tomów), uważanego za "słowo Buddy" (w tym przypadku Tönpy Szenraba Miwo), oraz Tandżuru (tyb. bstan 'gyur) tzw. „Katen” (tyb. bka' brten), będącego zbiorem tekstów komentarza. Podczas gdy buddyjski Tandżur składa się z tybetańskich tłumaczeń sanskryckich komentarzy buddyjskich, bönowski „Katen” to skompilowany zbiór ponad 2000 tekstów w 350 tomach. Zawiera on także wiele tekstów rytualnych, z których większość nie została jeszcze poddana badaniom naukowym.

Niektórzy wyznawcy bön twierdzą, iż ich religia (lub niektóre jej nurty) wywodzi się z zachodniego Tybetu. Jednak wszystkie dotychczas odkryte rękopisy (sprzed XI w.) pochodzą z Tybetu Centralnego. Według tradycji tybetańskiej bön przybył do środkowego Tybetu wraz z kapłanami z dawnego królestwa Szang Szung (Zhangzhung). Zostali oni zaproszeni do wykonania rytuałów pogrzebowych po śmierci dziewiątego mitycznego króla Tybetu ok. II w. n.e. Od tamtej chwili bön rozwijał się pod patronatem władców z Tybetu Centralneg, aż do czasów żyjącego w latach 742-797 króla Trisong Decena (tyb. khri srong lde btsan). Niemal całkowity brak wczesnych dzieł bön w zachodnim Tybecie może, jak utrzymują sami wyznawcy, być rezultatem systematycznego programu wykorzeniania religii bön realizowanego przez buddyjskich władców od X w., ale może też oznaczać, że nigdy tej tradycji we wczesnym okresie rozwoju tej religii tam nie było.

Dzisiaj religia bön, rozwijająca się w ośrodkach klasztornych, kwitnie zarówno w Tybecie, jak i w diasporze tybetańskiej na obszarze południowej Azji (a w ostatnich dekadach także w Europie i Stanach Zjednoczonych). Obecnie

Une lecture des Pelliot tibétain 1286, 1287, 1038, 1047, et 1290: essai sur la formation et l'emploi des mythes politiques dans la religion royale de Sron-bcan sgam-po, [in:] ibidem, s. 190-391; S.G. Karmay, The Arrow... Vol. 1, s. 157-166.

7 S. van Schaik, The Naming of Tibetan Religion: «Bon» and «Chos» in the Tibetan imperial period, „Journal of the International Association for Bön Research” 2013, t. 1, s. 227-257.

8 P. Wangdu (Pa-tshab Pa-sangs dbang 'dus), L.N. Tsering (Glang-ru nor-bu tshe-ring), Gtam shul dga' thang 'bum pa che nas gsar du rnyed pa'i bon gyi gna'dpe bdams bsgrigs, Lhasa 2007. 
nadal można znaleźć jej wyznawców na rozległym obszarze zachodniego Tybetu, szczególnie w okolicy góry Kajlas (będącej symbolem terytorium dawnego królestwa Szang Szung), ale także wśród Kinnaurów w północnych Indiach, w grupie Naxi w prowincji Yunnan w Chinach oraz w niektórych rejonach Bhutanu i północno-wschodnich Indii.

Religia bön jest coraz częściej przedmiotem akademickich badań, jakkolwiek nie należy zapominać, że ten składnik kultury tybetańskiej dopiero stosunkowo niedawno pojawił się w obszarze zainteresowań naukowców. Wcześniej ta tradycja była zwykle określana jako zbiór prymitywnych i szamanistycznych wierzeń. Ta obiegowa opinia była rozpowszechniana przez wieki przez szkoły buddyjskie w Azji. Dotychczas naukowe studia nad tą tradycją skupiały się na aspektach religijnych, które są najbardziej zbliżone do myśli buddyjskiej. Do najważniejszych opracowań w tym zakresie należą: The Nine Ways of Bön. Excerpts from «gZi-brjid»-edycja londyńska z 1967 w thumaczeniu Davida Snellgrove'a, The Bön Religion of Tibet..., wydana w Londynie w 1995 przez Pera Kvaerne'a oraz Unearthing Bön Treasures... z 2001 r., opublikowana w Lejdzie przez Dana Martina ${ }^{9}$. Współczesną wiedzę na temat bön zawdzięczamy również wspomnianemu już wcześniej S. Karmayowi, którego prace $\mathrm{z}$ różnych okresów zostały wydane pod tytułem The Arrow and the Spindle... (Katmandu 1998-2014) ${ }^{10}$. Podczas gdy większość powstałych dotychczas opracowań na temat bön zajmowała się historią, filozofią i systemami medytacyjnymi tej religii, nie podjęto właściwie w ogóle badań kultury materialnej wytworzonej przez tę tradycję.

Książka w tradycji bön: kolekcje, forma, materiały

Rękopisy religijne bön nie były tradycyjnie postrzegane jako zabytki. W efekcie czego nie zostały do tej pory wyraźnie zidentyfikowane jako odrębny korpus materiałów. Na Zachodzie ograniczone i często niekompletnie skatalogowane zbiory rękopisów bön znajdują się m.in. w Bibliotece Brytyjskiej (British Library), Szkole Studiów Orientalnych i Afrykańskich Uniwersytetu Londyńskiego (School of Oriental and African Studies, University of London), w zbiorach uniwersytetów w Oksfordzie i Cambridge. Współczesne ich przedruki można znaleźć na Uniwersytecie Wirginii (University of Virginia) w Charlottesville, Uniwersytecie Columbia (Columbia University) w Nowym Jorku, Centrum Bibliotek Naukowych (Centre for Research Libraries)

The Nine Ways of Bön. Excerpts from "gZi-brjid», ed. and transl. by D.L. Snellgrove, London 1967; P. Kvaerne, The Bön Religion of Tibet: The Iconography of a Living Tradition, London 1995; D. Martin, Unearthing Bön Treasures: Life and Contested Legacy of a Tibetan Scripture Revealer, with a General Bibliography of Bön, Leiden-Boston 2001.

10 S.G. Karmay, The Arrow... Vol. 1-3. 
w Chicago, Bibliotece Kongresu (Library of Congress) w Waszyngtonie oraz w znacznie mniejszych kolekcjach na kilku innych uniwersytetach. W latach 60. i 70. XX w. wydano kilkaset tomów dzieł bön w ramach programu Biblioteki Kongresu wykorzystując druk offsetowy.

Zgodnie z tradycją Tybetańczycy nie przywiązywali wagi do wartości historycznej poszczególnych egzemplarzy, a tym bardziej nie traktowali ksiąg jako zabytków kultury. W ostatnich latach jednak podjęto wiele wysiłków w celu zachowania dziedzictwa kulturowego Tybetu, w tym również zabezpieczenia manuskryptów religii bön. Przykładem może być inicjatywa Instytutu Paltseg w Lhasie sporządzenia spisu zachowanych ksiąg na obszarze Tybetańskiego Regionu Autonomicznego w Chinach, co doprowadziło do bezprecedensowych odkryć starych rękopisów. Pomogło to w oszacowaniu, jak duża liczba zbiorów przetrwała niszczącą siłę rewolucji kulturalnej w Chinach. Pomimo tak niekorzystnej dla Tybetu sytuacji politycznej, wiele cennych zbiorów ocalało i obecnie znajduje się w kolekcjach całego świata, między innymi w Polsce. W połączeniu ze zwiększonym zainteresowaniem buddyzmem, bön i literaturą tybetańską, mamy do czynienia obecnie z nową falą zainteresowania tybetańską książką, w tym również manuskryptami religii bön. To doprowadziło do zainicjowania bardziej systematycznych badań kodykologicznych, historycznych i antropologicznych związanych z ich powstawaniem.

Jednym z najbardziej typowych formatów tybetańskich ksiąg jest pecha (tyb. dpe cha), tradycyjny wolumen w formie luźnych kart w kształcie wydłużonego leżącego prostokąta. Taka forma określana czasem również terminem pothi, pochodzi od książek indyjskich napisanych na liściach palmowych. Tybetańczycy, jakkolwiek zaadoptowali formę książki z Indii, to na skutek braku liści palmowych w Tybecie wytwarzali księgi w formie papierowej. Tybetański papier był wyrabiany z włókien roślin z rodziny wawrzynkowatych (Thymelaeaceae), takich jak: Daphne, Edgeworthia, Wikstroemia i Stellera species $(s p p)^{11}$.

Karty indyjskich książek były nawleczone na sznur, którego końce mocowano do okładek, w przeciwieństwie do kart woluminów tybetańskich, które nie są w żaden sposób łączone. Niektóre tybetańskie księgi, również te przynależne do tradycji bön-szczególnie wybrane tomy dzieł kanonicznych - mają dwa małe kółka wykreślone na każdym folio (w miejscach, gdzie zwykle przeciągnięty był sznur łączący karty), jako rodzaj „hołdu” składanego swojemu prototypowi. Jakkolwiek powyżej opisany format jest dominujący,

11 A. Helman-Ważny, Overview of Tibetan Paper and Papermaking: History, Raw Materials, Techniques and Fibre Analysis, [in:] Tibetan Manuscript and Xylograph Traditions. The Written Word and Its Media within the Tibetan Culture Sphere, ed. O. Almogi, Hamburg 2016, Indian and Tibetan Studies, 4, s. 174-179. 
to znane są również tybetańskie księgi w formie zwoju, harmonijki, a także szyte $\mathrm{w}$ grzbiecie od góry lub z boku, podobnie jak europejski codex. Te ostatnie właśnie, znane jako tybetański $d e b$, zasługują na szczególną uwagę. Termin ten jest skrótem od starszego pojęcia deb ther oznaczającego „zapis” lub „kronikę”. Deb odpowiada perskiemu i arabskiemu daftar, co oznacza to samo. Natomiast daftar pochodzi z kolei od greckiej diphthera (,skóra") i oznacza powierzchnię piśmienniczą. Książki są zwykle owijane w płótno zwane pere (tyb. dpe ras), a następnie umieszczane pomiędzy dwiema drewnianymi okładkami. W takiej formie czasem są jeszcze dodatkowo obwiązane tkaniną lub skórzanym paskiem z klamrą. Pecha są zwykle przechowywane w świątyniach, klasztornych bibliotekach lub prywatnych domach (fot. 1).

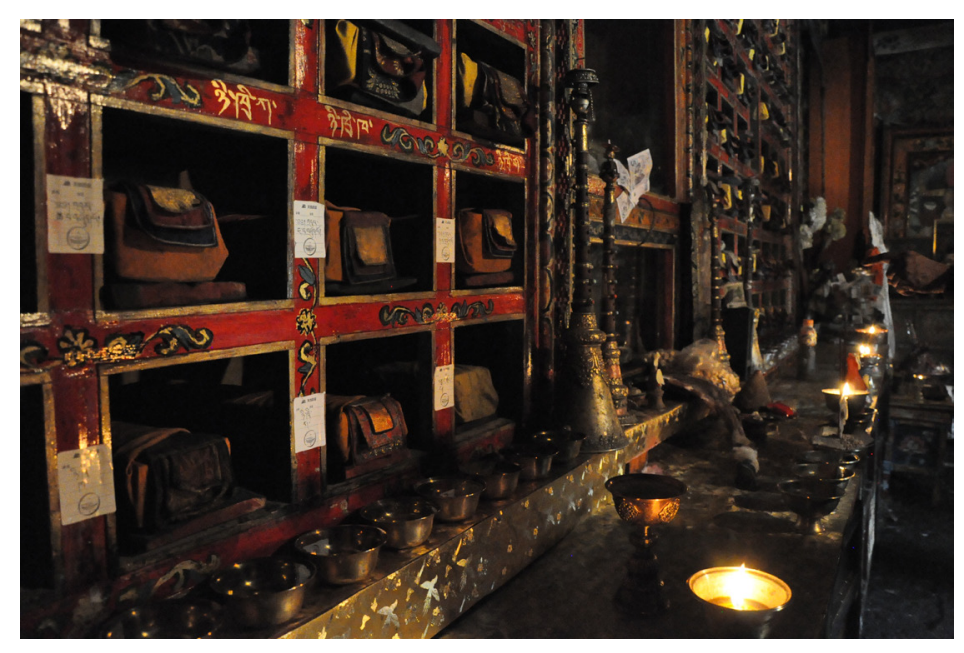

Fot. 1. Tybetańskie książki przechowywane w miejscowej bibliotece klasztornej. Zdjęcie: A. Helman-Ważny, 2013

Manuskrypty bön na pierwszy rzut oka nie różnią się od innych buddyjskich książek tybetańskich. Jednak takie wrażenie wynika głównie z braku systematycznych badań i zainteresowania materialną stroną tych zabytków piśmiennictwa. Istnieją jednak przekonujące dowody, że wyznawcy religii bön wypracowali własną tradycję przygotowania rękopisu, która wykracza poza różnice regionalne i historyczne osobliwości. Podczas gdy buddyzm ma długą i szeroko rozpowszechnioną tradycję kopiowania tekstów przy użyciu druku ksylograficznego, w tradycji bön zawsze faworyzowano użycie tekstu rękopiśmiennego, częściowo zapewne z powodu braku znaczącego mecenatu, który umożliwiłby wytworzenie desek ksylograficznych. Możliwe są jednak także przyczyny związane ze szczególnym traktowaniem procesu produkcji 
tekstu. W efekcie niemal wszystkie dotychczas znane teksty bön występują w formie manuskryptów. Do cech charakterystycznych tej tradycji należy na przykład użycie pewnych skrótów, specjalnego rodzaju pisma, symboli i innych cech, które rzadko lub w ogóle nie występują w tekstach buddyjskich. Podobnie zauważono, że niektóre egzorcystyczne rytuały wymagają użycia papieru, tuszu i narzędzi wykonanych ze specjalnych składników i według dokładnych receptur i rozmiarów. Jednak nie wiadomo, czy podobnymi regułami kierowano się przy produkcji rękopisów.

Podjęte przez autorkę badania ksiąg w rejonie Mustangu potwierdziły istnienie wielu kolekcji manuskryptów należących do tradycji bön. Niniejszy artykuł prezentuje jednak przede wszystkim wyniki badań nad zbiorem rękopisów z jaskiń Mardzong ${ }^{12}$.

\section{Odkrycie manuskryptów w jaskiniach Mardzong}

Rękopisy z Mardzong są wyjątkowo interesującym znaleziskiem archeologicznym. Kolekcję odszukano w 2008 r. w trudno dostępnym kompleksie jaskiń, położonym na południe od miasta Lo Monthang, w nepalskim Mustangu (fot. 2). Dokonała tego grupa himalaistów prowadzonych przez Brota Coburna i Petera Athansa (ekspedycja została udokumentowana w filmie National Geographic pt. Secrets of Shangri-La ${ }^{13}$ ). Manuskrypty są obecnie przechowywane w małym muzeum w kompleksie klasztoru Chöde wraz z innymi zabytkami z tego regionu. Muzeum jest w rzeczywistości niewielkim pomieszczeniem wypełnionym historycznymi eksponatami (fot. 3). Księgi są związane głównie z religią bön, pozostała ich część dotyczy tradycji buddyjskich, jak również spraw świeckich, np. prawa i literatury. Jednak większość nie-bönowskich tekstów uważa się obecnie za zaginione, gdyż od 2015 r. nie udało się ustalić, gdzie ta część kolekcji się znajduje. O jej istnieniu wiemy tylko z pobieżnej dokumentacji wykonanej w 2008 r. w trakcie wydobycia luźnych kart z jaskiń Mardzong.

Odkrycie kompleksu jaskiniowego Mardzong było dobrze udokumentowane przez różne ekipy filmowe, jednak po odnalezieniu i przemieszczeniu w 2009 r. ksiąg do klasztoru Chöde nie podjęto żadnych działań mających na celu ich naukową identyfikację. Dlatego nikt nie wiedział, co zawiera ta kolekcja i jaka była jej objętość. Za taką sytuację były prawdopodobnie

12 Badania, których wyniki przedstawiono w niniejszym artykule, przeprowadzone były w ramach projektu pt. „Manuskrypty z jaskiń Mardzong w Nepalu: analiza kolekcji, badania papieru i datowanie" finansowanego przez Narodowe Centrum Nauki w ramach konkursu „SONATA BIS 4" i realizowanego na Wydziale Dziennikarstwa, Informacji i Bibliologii UW w latach 2015-2018.

13 Secrets of Shangri La, [online] https://www.youtube.com/watch?v=D6idE9w3fHY [dostęp 14.10.2018]. 
odpowiedzialne zarówno presja czasu, jak i tradycyjna forma książki, tzn. duża liczba luźnych kart. Niestety, nie podjęto wówczas również żadnych profesjonalnych działań konserwatorskich w celu ochrony tego unikatowego znaleziska. W momencie wydobycia z jaskiń Mardzong kolekcja została oszacowana na ok. 25000 rękopiśmiennych kart należących do 100 różnych dzieł. Dopiero w trakcie naszej pracy karty zostały policzone. Wiadomo więc, że w klasztorze znajduje się obecnie (w 2018 r.) 5095 kart, które udało nam się we współpracy z Nyimą Drandul Gurungiem i Charlsem Ramble ułożyć w 22 (niestety niekompletne) tomy. W ramach naszego projektu wykonaliśmy dokumentację fotograficzną i badania tego, co pozostało z kolekcji.

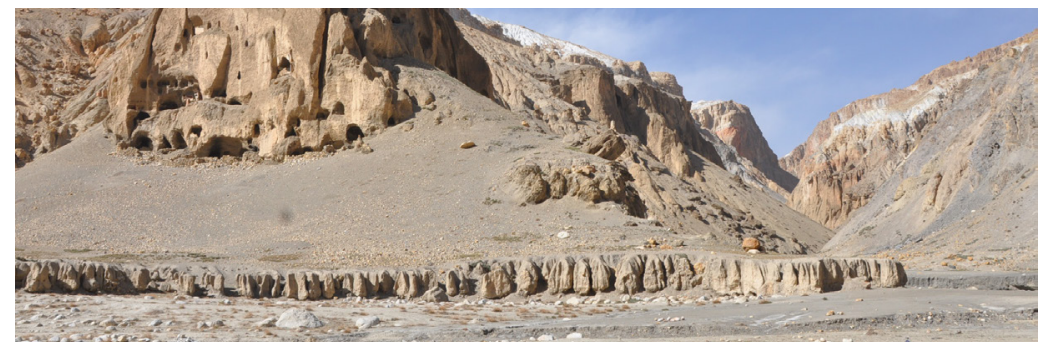

Fot. 2. Wzgórze Mardzong i jego okolice - miejsce odkrycia rękopisów w jaskini na wysokości ok. $3500 \mathrm{~m}$ nad poziomem morza. Zdjęcie: A. Helman-Ważny, 2016

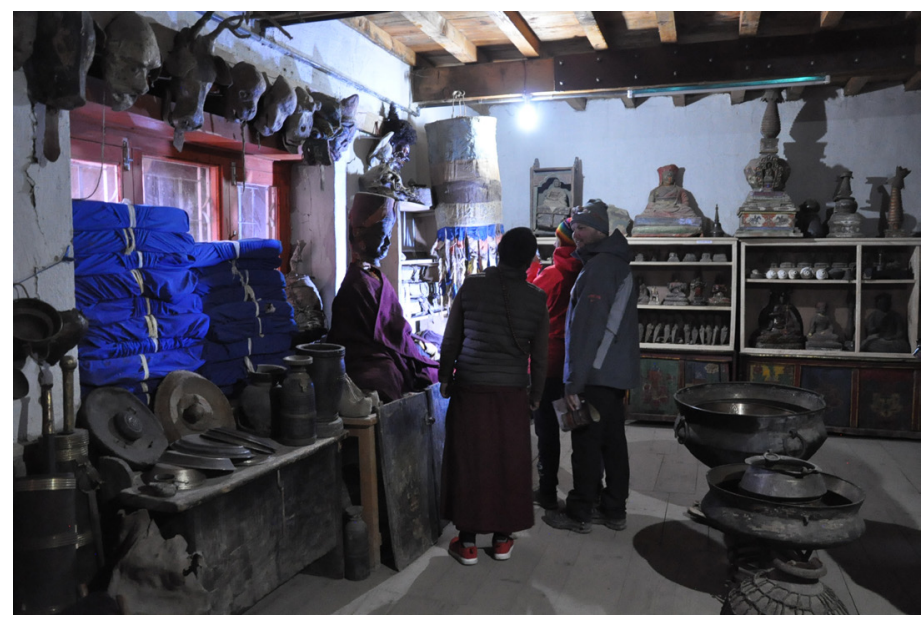

Fot. 3. Wnętrze muzeum w kompleksie klasztoru Chöde, gdzie przechowywane są obecnie manuskrypty z jaskiń Mardzong. Zdjęcie: A. Helman-Ważny, 2017 
Jaskinie Mardzong pełniły przez stulecia funkcję trudno dostępnego schronienia dla różnorodnych księgozbiorów, pochodzących prawdopodobnie z opuszczonych osad wokół Lo Monthang. Nie można jednak jednoznacznie stwierdzić, w jakich okolicznościach teksty znalazły się w tym miejscu. Rządząca w Królestwie Mustangu tybetańska dynastia została zapoczątkowana w XIV w. przez Amepala ( $a$ me dpal), którego potomkowie od tego czasu wspierali szkołę buddyzmu tybetańskiego Sakja (sa skya). W napisanej przez siebie historii Mustangu ostatni opat klasztoru Chöde, Trashi Tenzin (bkra shis bstan 'dzin) sugeruje, że przed ustanowieniem dynastii ziemia była trzymana w ciemnościach przez wyznawców religii bön i dopiero Amepal i jego następcy wyplenili starożytną wiarę i zastąpili ją buddyjską dharmą ${ }^{14}$. Jedna z hipotez o proweniencji rękopisów sugeruje, że księgi mogły pochodzić z jednej lub kilku prywatnych bibliotek należących do pobliskich osad porzuconych przez mieszkańców po założeniu stolicy regionu Lo Monthang lub też w momencie, gdy pojawienie się buddyzmu wyparło oryginalną tradycję bön. Jednak kolekcja zawiera również księgi należące do kanonu buddyjskiego, a to wskazuje raczej, że przyczyny złożenia manuskryptów w jaskiniach mogą być bardziej złożone.

Odkryte manuskrypty reprezentują jeden z najbardziej typowych formatów tybetańskich ksiąg, jakim jest wspomniana powyżej pecha (tyb. dpe cha) - tradycyjny zbiór luźnych kart. Można się jedynie domyślać, że znalezione tomy z Mardzong oryginalnie zawierały również zwykle bogato zdobione drewniane okładziny, tkaniny dpe ras ochraniające karty, jak również dodatkowe, także zwykle bogato zdobione karty tytułowe. Na obecność tych ostatnich wskazują fragmenty kart malowanych indygo oraz pojedyncze wycięte iluminacje. Niestety, żaden z wymienionych powyżej elementów nie zachował się w poszczególnych woluminach tworzących kolekcję. Jakkolwiek nie można wykluczyć, że w jaskiniach złożone zostały jedynie karty, gdyż wniesienie ciężkich okładek mogło być zbyt kłopotliwe. Poza tym te same okładki często były używane do różnych tomów, w zależności od potrzeb. Jest więc bardzo prawdopodobne, że oryginalne okładki nigdy nie trafiły do jaskiń Mardzong.

\section{Teksty zachowane w księgach z Mardzong}

Znaczna część zachowanego zbioru stanowi teksty religijne należące do tradycji bön. Udało się wyodrębnić 16 tomów Khamchen (tyb. khams chen), będących odpowiednikiem buddyjskiej Prajnaparamity „Doskonałości

14 C. Ramble, informacja ustna. 
Mądrości"15. Zgodnie z historyczną tradycją bön ów zbiór tekstów uważa się za nieoparty na buddyjskich wzorcach. Wyznawcy bön uważają go bowiem za oryginalny przekaz nauk mitycznego założyciela Tönpy Szenraba Miwo, który według tej tradycji wyprzedza Buddę Siakjamuniego (ok. 563-483 p.n.e.) o kilka tysięcy lat. Uznaje się, że dzieło to zostało ukryte jako święty skarb - terma (tyb. gter ma), a następnie odkryte na nowo przez najsławniejszego „odkrywcę skarbów” bön, Shenchen Luga (tyb. gshhen chen klu 'dga') żyjącego na przełomie X i XI w. n.e. Pośród odnalezionych tomów znajduje się również jedna skrócona wersja Khamchen znana jako Kadü (tyb. ka 'dus).

W badanej kolekcji znalazły się również dwa tomy należące prawdopodobnie do różnych wydań tekstu określanego jako Lubum Karpo (tyb. klu 'bum dkar po). Wśród głównych dzieł kanonicznych bön znajdowały się co najmniej trzy różne zestawy tego tekstu. Lubum - „Setki tysięcy Wężowych Duchów" - jest dziełem, dla którego nie istnieje żaden odpowiednik buddyjski. W przeciwieństwie do tekstu Khamchen, którego jednoznaczna przynależność do tradycji bön jest kwestionowana, uważa się go powszechnie za rdzenny tekst bön. Podobnie jak Khamchen, Lubum jest klasyfikowany jako święty tekst (terma), tzn. w takim stopniu, w jakim przypisuje się go twórcy religii Tönpie Szenrabowi Miwo. Jej wyznawcy sądzą, że później tekst ten został ukryty, aby uchronić go przed prześladowaniami buddyjskimi w VIII w., a następnie ponownie odkryty w X w.

Czwartym kanonicznym dziełem bön, którego egzemplarz znajduje się w kolekcji Mardzong, jest Zermik (tyb. gzer mig) - jedna z trzech głównych hagiografii Tönpy Szenraba Miwo. Najkrótszą i najstarszą jest Dodü (tyb. $m d o$ bsdus), prawdopodobnie pochodząca z XI lub XII w., a najdłuższą Ziji (tyb. gzi brjid), dwunastotomowe dzieło z XIV w. Zermik powstał prawdopodobnie w XII lub XIII w. i występuje zwykle w dwóch tomach. Wersja znaleziona w Mardzong, a także inne zachowane w prywatnych kolekcjach w Mustangu, są najczęściej spisane w jednym woluminie. Ponieważ karty ułożyliśmy w oparciu o rozmiar folio, może się zdarzyć, że niektóre tomy zawierają folio o podobnej wielkości z różnych kopii tych prac. Istnieje też berlińska kopia tego tekstu (gzer mig), którą Austin Waddell przywiózł z Tybetu po brytyjskiej ekspedycji wojskowej Francisa Younghusbanda w 1904 r.

W kolekcji znajduje się również jeden tom należący do Kanonu Buddyjskiego, a mianowicie „cha” (t. 6) z tekstem Kausika-Sutra.

15 tomów Khamchen, które udało się wyodrębnić to: „ka” (1), „kha” (2), „ga” (3), „nga” (4), „,ca” (5), ,cha” (6), ,ja” (7), ,nya” (8), ,ta” (9), „tha” (10), ,da” (11), ,na” (12), ,pa” (13), „pha” (14), „ba” (15), ,aa” (30). Poza tym odnaleziono pojedynczą kartę z tekstem kolofonu. 


\section{Badania kodykologiczne manuskryptów z Mardzong}

Wszystkie karty woluminów należące do kolekcji Mardzong są manuskryptami. Nie jest to jednak nic szczególnego, ponieważ, jak wspomniano powyżej, tradycja bön właściwie nie wykształciła książki drukowanej. Napisane są pismem uczen (tyb. dbu can), średnio w ośmiu wersach tekstu na stronie $^{16}$. Jedynie na pierwszych kartach liczba wierszy tekstu jest mniejsza, co jest typowe dla książek tybetańskich.

Wymiary poszczególnych kart wchodzących w skład wyżej wymienionych 16 tomów (przypis 14) są do siebie zbliżone, aczkolwiek nieidentyczne. Mieszczą się w granicach od 20 do 21,5 cm wysokość i od 64,5 do $66 \mathrm{~cm}$ szerokość ${ }^{17}$. Nie można mieć absolutnej pewności, czy te różnice wynikają z niedokładności przy przygotowaniu kart, czy też może poszczególne grupy tomów mogły być wykonane w innym czasie lub też przez inne osoby. Technika wykonania, kompozycja strony, jak również styl iluminacji oraz rodzaj zastosowanych materiałów piśmienniczych, pomimo pewnych różnic, wskazuje na przynależność tomów do tego samego wydania Khamchenu. Przy czym różnice mogą sygnalizować wymianę niektórych, być może zniszczonych woluminów, na nowe, sporządzone później tomy. Pełne wydanie było zwykle przygotowywane przez dużą grupę rzemieślników, skrybów i artystów. Tak więc nie powinno dziwić, że widoczne są indywidualne cechy w poszczególnych tomach tekstów, prawdopodobnie tego samego wydania. Edycja Kadü (tyb. $k a$ 'dus) mierzy $22 \times 66 \mathrm{~cm}$.

Układ tekstu na stronie, podobnie jak rozmiar kart, jest typowy dla tybetańskich ksiąg kanonicznych. Jednak układ strony także nie jest identyczny w poszczególnych tomach. Cechą wspólną jest skomponowanie tekstu w ramce wykreślonej pojedynczą lub podwójną czerwoną linią na kilku pierwszych stronach, a następnie pomiędzy bocznymi marginesami narysowanymi tym samym narzędziem i kolorem. Charakterystycznym elementem są koła, również wykreślone czerwonym tuszem w miejscach, gdzie zwykle przeciągano sznur w książkach poti wykonanych na liściach palmowych.

Większość tomów jest ilustrowana; zwykle każdy zawiera do dziesięciu iluminacji. Ikonografia przedstawia lokalne bóstwa, lamów, święte miejsca lub patronów. Ilustracje namalowane są płasko kolorem, a następnie oznaczone

16 Na przestrzeni wieków właściwie najczęściej używane były dwa typy pisma: pismo proste, równane do górnej linii tekstu (tzw. pismo uczen - tyb. dbu can), lub jego tzw. ,bezgłowa” wersja pisana, odmiana ume ( $d b u$ med).

17 Tomy o wymiarach 21-21,5×65,5 cm to „ka” (1), ,kha” (2), „ga” (3), „nga” (4), ,ja” (7), „nya” (8), „da” (11), „na” (12), „,aa” (30). Tomy o wymiarach 20,5×65-65,5 cm to tomy „ca” (t. 5), „cha” (6), ,tha” (10). Tomy o wymiarach $21 \times 66 \mathrm{~cm}$ to tomy ,pa” (13), ,pha” (14), ,,ba” (15). Tom „ta” (9) wyróżnia się najbardziej, gdyż jego karty mierzą $20 \times 64 \mathrm{~cm}$. Karta kolofonu mierzy $21 \times 64,5 \mathrm{~cm}$. 
czarnym lub czerwonym konturem. Wymiary tych ilustracji nie są jednakowe, jak również ich położenie. Jest to ciekawe, gdyż w tybetańskich wydaniach kanonu buddyjskiego ilustracje zwykle umieszczone są po obydwu stronach tekstu. Taką kompozycję można zobaczyć w tomie „ga” (t. 3). W większości innych tomów ilustracje są wkomponowane w różne miejsca tekstu i mają odmienne wymiary. Tego typu kompozycja miniatur z kolei występuje czasem w księgach pochodzących z zachodniego Tybetu. Jak widać jest również typowa dla analizowanej kolekcji (fot. 4 i 5).
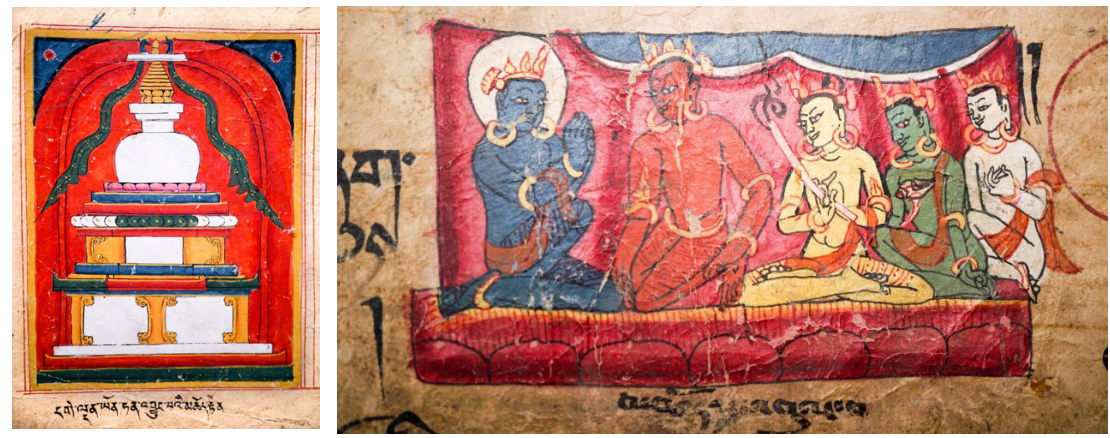

Fot. 4, 5. Po lewej stronie przedstawienie stupy (Dge ldan yon tan 'byung pa'i mchod rten) w tekście Khamchen tomu ,ga” (3) na stronie $358(+++58)$; po prawej złożenie ofiary (Mchod pa 'bul ba) w tekście Lubum na stronie 227 (++27). Zdjęcie: Kemi Tsewang, 2016

W niektórych przypadkach pierwsze karty zamiast miniatur z przedstawieniami postaci zawierają zdobienia geometryczne bocznych marginesów, tak jak to widać w tomie ,ta" (t. 9, fot. 6).

Manuskrypty zawierają także inne elementy kodykologiczne, charakterystyczne dla religii bön. Przykładem jest zastosowanie do adnotacji tekstu odwrotnej swastyki (z ramionami zwróconymi przeciwnie do ruchu wskazówek zegara), która jest jednym z głównych symboli religii bön. W niemal wszystkich księgach z kolekcji Mardzong adnotacje i uzupełnienia tekstu były sygnalizowane przez zamieszczenie tego znaku (zob. fot. 7). Symbol solarny, a także symbol pomyślności, szczęścia i prawdy, swastyka była wykorzystywana tutaj jako znak edytorski.

Karty zawierają foliację tybetańską umieszczoną prostopadle do tekstu na lewym marginesie, wykonaną podobnie jak tekst pismem uczen. Natomiast charakterystycznym elementem nieobecnym w innych książkach tybetańskich jest użycie znaku „," na oznaczenie stu kart. Jednak trzeba zaznaczyć, że zastosowanie „," występuje tylko w części kart zbioru. Można również znaleźć tradycyjny sposób zapisu liczebników przy użyciu tybetańskiego pisma. 


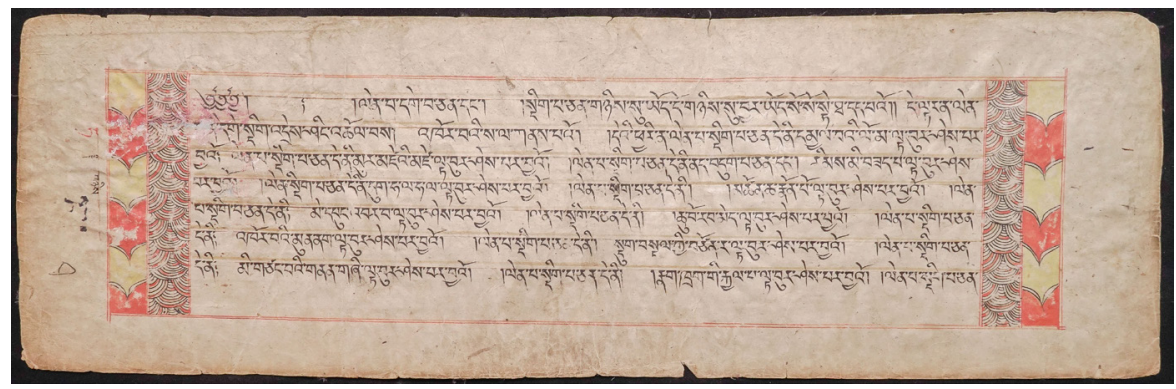

Fot. 6. Karta z tomu dziewiątego Khamchen („ta”) z kolekcji Mardzong. Widoczne geometryczne zdobienia bocznych marginesów. Zdjęcie: K. Tsewang, 2016

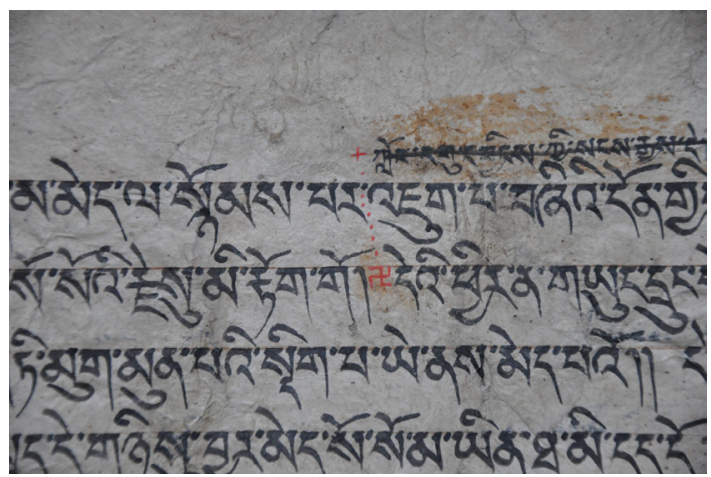

Fot. 7. Sposób wstawienia brakującego tekstu. Tom dziewiąty Khamchen („ta”) z kolekcji Mardzong. Zdjęcie: K. Tsewang, 2016

Niemal wszystkie tomy są napisane na papierze ręcznie czerpanym przy użyciu formy pływającej z sitem tkanym (fot. 8).

Badania mikroskopowe wykazały obecność włókien roślin z rodziny wawrzynkowatych (Thymelaeaceae), takich jak Daphne i Stellera spp. Włókna te są typowe dla ksiąg tybetańskich, jednak biorąc pod uwagę obszar występowania tych roślin możemy wnioskować, że surowce do produkcji papieru pochodziły z różnych źródeł. Położenie Płaskowyżu Tybetańskiego i jego ekstremalne warunki klimatyczne sprawiają, że roślinność tam występująca różni się od roślinności z innych obszarów Azji. Tak więc na tej podstawie wiemy, że Stellera spp. zidentyfikowana w papierze ksiąg z Mardzong była stosowana jedynie w Tybecie na wysokościach powyżej $3000 \mathrm{~m}$ nad poziomem morza, gdzie nie występują inne rośliny nadające się do produkcji papieru ${ }^{18}$ (fot. 9).

18 A. Helman-Ważny, Overview of Tibetan Paper..., s. 177-178. 


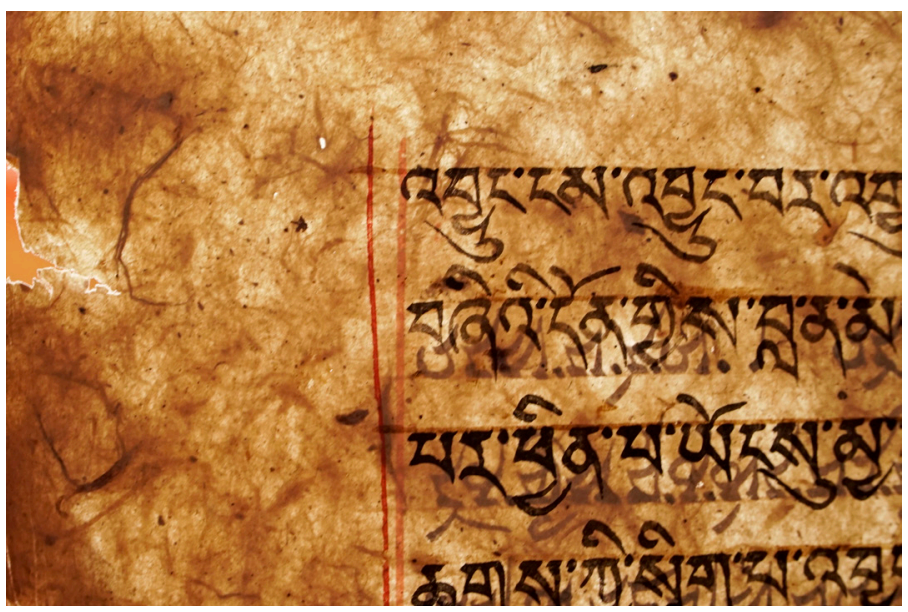

Fot. 8. Karta z tomu dziewiątego Khamchen („ta”) z kolekcji Mardzong. Widoczne przeźrocze papieru wyprodukowanego przy użyciu formy papierniczej pływającej z sitem tkanym. Zdjęcie: K. Tsewang, 2016

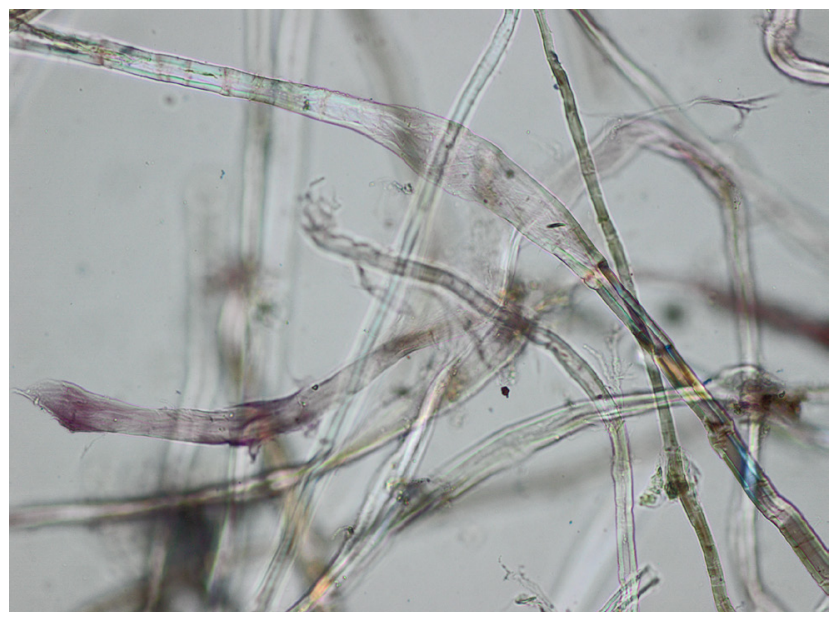

Fot. 9. Włókna Stellera sp. oraz Daphne/Edgeworthia sp. zidentyfikowane w tomie dziewiątym Khamchen („ta”) z kolekcji Mardzong. Zdjęcie: A. Helman-Ważny, 2017

Natomiast papier z włókien Daphne pochodził prawdopodobnie z rejonu położonego na południe od Mustangu, odpowiadającego dzisiejszym: Myagdi, Baglung lub Pharbat. Te prowincje charakteryzujące się bujnymi lasami, łagodniejszą temperaturą oraz gruntami odpowiednimi dla rolnictwa, do dzisiaj są znane ze swojej tradycji produkcji papieru i stanowią obszar pozyskiwania roślin papierniczych. 


\section{Datowanie manuskryptów z Mardzong}

Informacje na temat okoliczności powstania woluminów z Mardzong zostały podane w dedykacji, która została odnaleziona wśród wielu innych luźnych kart w jaskiniach. W tym przypadku nie jesteśmy w stanie stwierdzić, czy mamy do czynienia z dedykacją, czy kolofonem, gdyż numer strony nie zachował się z powodu ubytku fragmentu karty (fot. $10 \mathrm{a}, \mathrm{b}$ ).
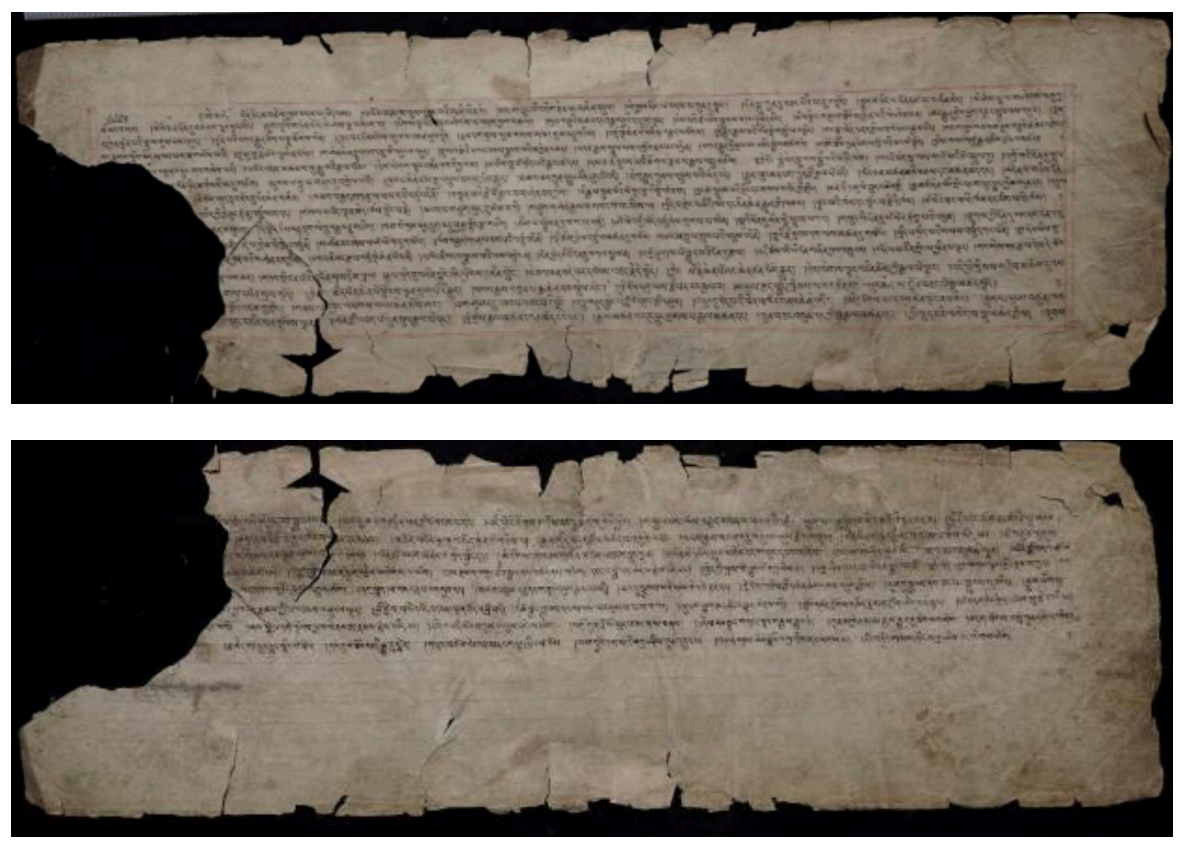

Fot. 10 a, b. Kolofon-dedykacja załączona oryginalnie do wydania tomów Khamchen z kolekcji Mardzong ( $\mathrm{a}$ - recto i b - verso). Zdjęcie: K. Tsewang, 2016

Prezentowana karta nie zawiera żadnych iluminacji ani zdobień. Różni się też kompozycją stron od reszty tomów. Zapewne dlatego, że więcej tekstu musiało zmieścić się na obu stronach. Zwyczajowo tekst zarówno kolofonu, jak i dedykacji, nie przekraczał jednej karty. W przeciwieństwie do ozdobnych kart tytułowych, karty dedykacji lub kolofonu nie mają wartości komercyjnej. Zapewne z tego powodu zostały pominięte przez szabrowników. Mieliśmy zatem szczęście, że kartę dedykacji pozostawiono w jaskiniach.

Według thumaczenia C. Ramble`a dedykacja (lub kolofon), załączona do zbioru tomów z Mardzong, rozpoczyna się od hołdu dla bóstw oraz przodków zapewne skryby. Następnie zawiera serię pochwał dla pobożnych mecenasów, 
którzy sponsorowali produkcję tekstu ${ }^{19}$. Z tegoż przekładu można się także dowiedzieć, że wydanie Mardzong należy do jednego z sześciu tybetańskich protoklanów Dong (tyb. ldong). Mecenasi są wymienieni, a jeden z patronów, Gyaltsen Yungdrung, ma imię wyznawcy bön. Miejsce, w którym żyją, opisane jest jako święte miejsce Bönkhor, położone na wschód od góry Kajlas i na południe od rzeki Pakshu (Bramaputra). Wymieniony w tekście dedykacji minister „Agon Zangpo” może być według C. Ramble’a synem i następcą Amepala. Jeśli ta dedykacja została napisana za jego panowania (urodził się w 1420 r.), to moglibyśmy datować analizowany egzemplarz Khamchenu na połowę XV w. Jeśli jednak wcześniej postawiona hipoteza, że kolekcja Mardzong została ukryta $\mathrm{w}$ jaskiniach z powodu wrogiego nastawienia pierwszych władców Mustangu do religii bön byłaby prawdziwa, to można by założyć, że księgi powstały przed założeniem dynastii w 1384 r. Tymczasem przeprowadzone badania radiowęglowe wskazują, że czas powstania poszczególnych tomów rożni się. Historia ich powstania jest więc zapewne bardziej złożona. Według analizy C14 część zachowanych woluminów z Mardzong zostało napisane nieco wcześniej niż wskazuje na to tekst kolofonu (fot. 11).

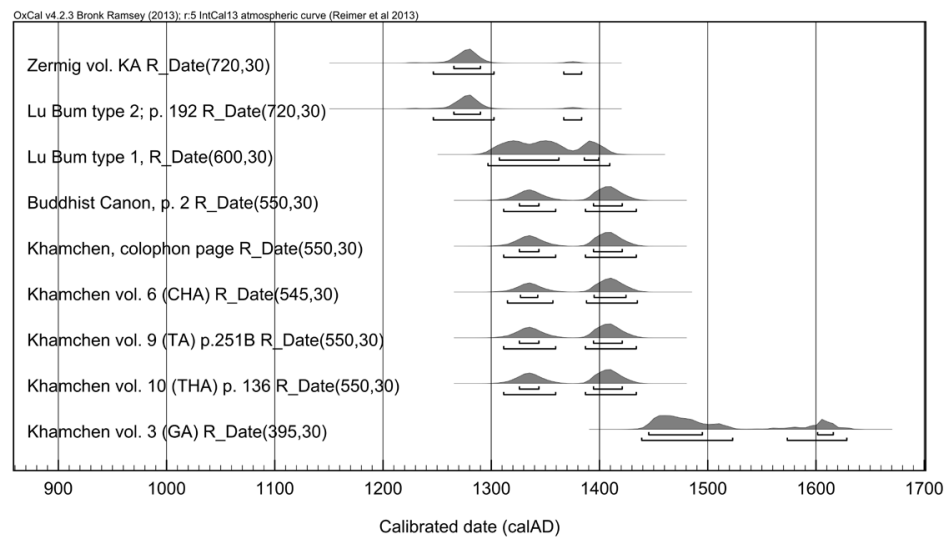

Fot. 11. Wyniki datowań C14 wybranych tomów z kolekcji Mardzong.

Zermik i Lubum datowane są na XIII w., a większość innych woluminów Khamchen, w tym kolofon, datowane są na XIV lub na początek XV w. Można tę rozbieżność wytłumaczyć hipotezą, że skryba używał papieru, który był wcześniej przechowywany, a następnie został użyty za czasów syna

19 Tłumaczenia kolofonów zostały wykonane przez N.D. Gurung i C. Ramble`a; zob.: C. Ramble, Translations of selected works from the Mardzong collection, [in:] A. Helman-Ważny et al., The Mardzong Manuscripts: Preservation, Interpretation and Dating of an Archaeological Find in Mustang, Nepal 2018 (w druku). 
i następcy Amepala. Należy też jednak wziąć pod uwagę, że datowanie C14 nie jest wystarczająco precyzyjne, aby zawęzić przedział czasowy do kilku lat. Tak więc różnica może być jedynie „niedokładnością” i wtedy zapewne należałoby datować teksty Khamchen na początek XV w.

\section{Podsumowanie}

Kolekcja manuskryptów (22 tomy) z jaskiń Mardzong, datowana na XIII-XV w., jest wyjątkowym odkryciem archeologicznym. W ogromnej większości należy do religijnej tradycji bön. W jej skład wchodzi: 16 tomów Khamchen; jeden tom jego skróconej wersji znanej jako Kadü; dwa tomy należące prawdopodobnie do różnych wydań tekstu określanego jako Lubum Karpo, jeden tom Zermik oraz jeden kanoniczny tom buddyjski „cha” (t. 6) z tekstem Kausika-Sutra. Poszczególne tomy składające się z luźnych kart wpisują się formalnie w tradycję książki tybetańskiej, lecz zawierają też elementy wskazujące jednoznacznie na ich przynależność do religii bön. Należy zwrócić tutaj szczególną uwagę na użycie symbolu swastyki jako znaku edytorskiego, jak również oznaczenie stu kart symbolem „,+, widoczne w foliacji na lewym ich marginesie. Natomiast kompozycja ilustracji, jak również styl i technika wykonania wskazują na podobieństwo do tradycji ilustrowania ksiąg w zachodnim Tybecie. W poszczególnych tomach zidentyfikowano włókna roślin Daphne i Stellera spp co sugeruje, że użyto papieru pochodzącego zarówno z wyżej położonych terenów Płaskowyżu Tybetańskiego, jak również z obszarów położonych na południe od Mustangu, znanych powszechnie z kultywowania rzemiosła papierniczego. Warto zaznaczyć, że jest to pierwsza kolekcja ksiąg z Mustangu, która stała się obiektem badań kodykologicznych.

\section{Bibliografia}

Cantwell C., Mayer R., Enduring myths: «smrang», «rabs» and ritual in the Dunhuang texts on Padmasambhava, „Revue d'Etudes Tibétaines” 2008, t. 15, s. 289-312.

Helman-Ważny A., Overview of Tibetan Paper and Papermaking: History, Raw Materials, Techniques and Fibre Analysis, [in:] Tibetan Manuscript and Xylograph Traditions. The Written Word and Its Media within the Tibetan Culture Sphere, ed. O. Almogi, Hamburg 2016, Indian and Tibetan Studies, 4, s. 171-196.

Karmay S.G., The Arrow and the Spindle. Studies in History, Myths, Rituals and Beliefs in Tibet. Vol. 1-3, Kathmandu 1998-2014.

Kvaerne P., The Bön Religion of Tibet: The Iconography of a Living Tradition, London 1995. Lalou M., Fiefs, poisons et guerisseurs, „Journal Asiatique” 1958, t. 246, s. 157-201. 
Macdonald A., Une lecture des Pelliot tibétain 1286, 1287, 1038, 1047, et 1290: essai sur la formation et l'emploi des mythes politiques dans la religion royale de Sron-bcan sgam-po, [in:] Études tibétaines dédiées à la mémoire de Marcelle Lalou, ed. A. Spanien, Paris 1971, s. 190-391.

Martin D., Unearthing Bön Treasures: Life and Contested Legacy of a Tibetan Scripture Revealer, with a General Bibliography of Bön, Leiden-Boston 2001.

Ramble C., Translations of selected works from the Mardzong collection, [in:] A. Helman-Ważny et al., The Mardzong Manuscripts: Preservation, Interpretation and Dating of an Archaeological Find in Mustang, Nepal 2018 (w druku).

Schaik S. van, The Naming of Tibetan Religion: «Bon» and «Chos» in the Tibetan imperial period, „Journal of the International Association for Bön Research” 2013, t. 1, s. 227-257.

Stein R.A., Du récit au rituel dans les manuscrits tibétains de Touen-Houang, [in:] Études tibétaines dédiées à la mémoire de Marcelle Lalou, ed. A. Spanien, Paris 1971, s. 479-547.

The Nine Ways of Bön. Excerpts from «gZi-brjid», ed. and transl. by D.L. Snellgrove, London 1967.

Wangdu P. (Pa-tshab Pa-sangs dbang 'dus), Tsering L.N. (Glang-ru nor-bu tshe-ring), Gtam shul dga' thang 'bum pa che nas gsar du rnyed pa'i bon gyi gna' dpe bdams bsgrigs, Lhasa 2007. 